[Vicino Oriente XXIII (2019), pp. 23-46]

\title{
AN AMPHORA WITH PAINTED PALMETTE MOTIF FROM AREA B AT MOTYA
}

\author{
Fabiola Zielli* - Sapienza University of Rome
}

\begin{abstract}
An amphora painted with a palmette motif dating from the $4^{\text {th }}$ century $B C$ was brought to light during the excavation of the Area B at Motya in 1989. The shape is a popular amphora type in the Punic ceramic repertoire, while the decoration, both in design and iconography, appear as an outcome of shared and hybridized motifs between the Phoenician and the Greek elements co-habiting in Motya during its latest phase of life.
\end{abstract}

Keywords: Motya, Area B; palmette; painted decoration; Punic amphora

\section{INTRODUCTION}

Area B, on the south-eastern slope of the Acropolis of Motya, was investigated in a series of excavation campaigns jointly carried out between the end of the "80ies and the beginning of the '90ies of the last century by the Superintendence of Trapani and Sapienza University of Rome. Field excavations were directed by Antonia Ciasca, in her latest work in the island. The find which is the object of this note was found in 1989. ${ }^{1}$ Area B includes the southern border of a residential quarter, that in the $5^{\text {th }}$ century BC extended all over the eastern slope of the Acropolis (fig. 1). ${ }^{2}$ The gentle slope of this towards the west was then occupied also by an industrial and commercial zone down to the Sacred Area of the Kothon.

The area gave back many noteworthy finds: metals, weights, ${ }^{3}$ a distinguished series of terracottas ${ }^{4}$ - which may suggest the presence of a major cult place in the area - pottery vessels among which a painted Punic amphora (fig. 2), ${ }^{5}$ decorated with a frieze of palmette, an unique attestation at Motya for this decorative motif. The study of this vessel revealed that it was imported rather than manufactured on the island ( $\$ 2.2)$. Furthermore, its presence at Motya in a post-Dionysian destruction layer ${ }^{6}$ testifies to the continuous importation of special ceramics also during the latest Punic occupation of the island.

\footnotetext{
* PhD student in Phoenician-Punic Archaeology at "La Sapienza" University of Rome; fabiola.zielli@uniroma1.it. I would like to thank Professor Lorenzo Nigro and Dr. Maria Pamela Toti for allowing me to study the amphora with painted palmette motif.

1 Excavations in Area B were carried out by the Superintendence of Trapani and were directed by Antonia Ciasca on behalf of "La Sapienza" University of Rome, with the collaboration of Maurizio Necci, Pamela Tot and Maria Luisa Famà (Famà - Toti, 1997, 113, fn. 2; Famà ed. 2002, 28, fn. 17; Nigro ed. 2004, 27; 2012, 210).

2 Along the northern side of the street, which divides the residencies from the commercial zone, Sapienza Archaeological Expedition to Motya identified a wealth patrician house called "The House of the square well": Nigro ed. 2012, 210. Results of previous excavations season are summarized in Famà 1990, 13; 1995, $424 ; 1997,643-644$

3 Gallo 2018, 35-41.

$4 \quad$ Nigro ed. 2012, 210

Spagnoli 2019, 43, fig. 3.35

Nigro 2018, 254.

ISSN 0393-0300

e-ISSN 2532-5159

Rivista Open Access
} 


\section{THE CONTEXT OF THE DISCOVERY}

Area B was occupied from the first Phoenician foundation of Motya, at the beginning of the $8^{\text {th }}$ century $\mathrm{BC}^{7}$ to the fall of the city under the siege of Dionysius of Syracuse $(397 / 6$ BC).$^{8}$ In its latest arrangement $\left(5^{\text {th }}\right.$ century BC, Motya VII), Area B was crossed by a large plateia which divided the wealthy residencies, to the north, from the row of workshops and ateliers running along the southern side of the street (fig. 3). Both the furniture of the houses and imported items found into the commercial block, testify to the wealth of the inhabitants due to their intense commercial activities. ${ }^{9}$ After the conquest by Dionysius of Syracuse, many structures were re-used for industrial activities. Already existing buildings were often cut through and damaged by the excavations of wells and ovens. ${ }^{10}$

The amphora with palmette was found in filling US.24. This layer was affected by agricultural activities conducted in the $19^{\text {th }}$ century and by the excavation of pits for vineyards which disturbed the layers of the $5^{\text {th }}-4^{\text {th }}$ century BC. ${ }^{11}$ The ceramic repertoire of US.24 (fig. 4) represents the twofold functional destinations of the area in the $4^{\text {th }}$ century BC: residential and industrial, and basically includes Punic storage jars, Simple Ware (SW) and Attic pottery, as a fine cup with baccellation ${ }^{12}$ (fig. 6).

Simple Ware (fig. 5) is mostly local manufactured. ${ }^{13}$ The uppermost functional class represented is tableware, as exemplified by three jugs dating from the $4^{\text {th }}$ century $\mathrm{BC}^{14}$ (fig. 7) and two from the $5^{\text {th }}$ century $\mathrm{BC}^{15}$ (fig. 7). A basin bowl ${ }^{16}$ (fig. 7), a miniature jar ${ }^{17}$ (fig. 6 ), both dated in the $4^{\text {th }}$ century $\mathrm{BC}$, and a bucket of $5^{\text {th }}$ century $\mathrm{BC}^{18}$ (fig. 6 ) were also found. Transport jars are represented by a Lesbian amphora dated from the $5^{\text {th }}$ century $\mathrm{BC}^{19}$ (fig. 6), one Punic amphora for storage ${ }^{20}$ (fig. 6) and one Punic amphora for transport ${ }^{21}$ (fig. 6 ) of the $4^{\text {th }}$ century $\mathrm{BC}$, attesting the continuation of the commercial function of the area.

Famà 1990, 13; 1995, 424; 1997, 643-644; Nigro ed. 2010, 276-318; Nigro - Spagnoli 2017.

Tusa 1967, 85-95.

In general, about the contacts between Motya and the Greek culture: Bondì 1989, 165-173; Nigro ed. 2010, 148; Spagnoli 2019, 65; concerning the Greek ceramics in the Area B of Motya: Zielli 2016, La ceramica della "Zona B" di Mozia. Catalogo preliminare della ceramica rinvenuta nello scavo di Antonia Ciasca, 1989, defensed on $26^{\text {th }}$ September 2016, at "La Sapienza" University of Rome.

10 Ovens of Area E at Motya shows similar features, attributed to the phase between the $4^{\text {th }}$ and the $3^{\text {rd }}$ century BC (Famà - Toti 1997, 113-114; Famà ed. 2002, 48).

Famà ed. 2002, 48.

Athenian Agorà XII, 279, fig. 6:612. This type is attested from $420 \mathrm{BC}$ onwards.

The common ceramic is the $32 \%$ of the total (fig. 5).

4 MB.89.24/21 cf.: Nigro ed. 2004, 286, MD.02.216/47, pl. LXI. MB.89.24/9 cf.: Nigro ed. 2011, 332, MF.05.1294/20, pl. CI. MB.89.24/23 cf.: Nigro ed. 2011, 238, MF.05.1268a/104, pl. LIII.

15 MB.89.24/20 cf.: Nigro ed. 2007, 208, MD.03.1036/24, pl. XLIX. MB.89.24/26 cf.: Nigro ed. 2005, 314, MC.04.701/1, pl. XC.

MB.89.24/24 cf.: Vecchio 2002, 227, type 57, pl. 19:1.

MB.89.24/25 cf.: Nigro ed. 2007, 224, MD.03.1048/9, pl. LVII.

MB.89.24/22 cf.: Vecchio 2002, 262, type 158, n. 5, pl. 54.

MB.89.24/25 cf.: Nigro ed. 2005, 312, MC.04.715/15, pl. LXXXIX.

MB.89.24/4 cf.: Nigro ed. 2005, 300, T35, MC.04.709/22, pl. LXXXIII.

21 MB.89.24/10 cf.: Nigro ed. 2005, 358, T20, MC.04.939/5, pl. CXII. This type isn't local, and it is spread over Area B. 


\section{THE AMPHORA WITH PALMETTE}

The amphora with palmette, MB.89.24/3 (fig. 2), belongs to a late reformulation of the slightly "carinated shoulder" type, spreads over in the Center-Western Mediterranean, between the $5^{\text {th }}$ and the $4^{\text {th }}$ century BC. ${ }^{22}$

\subsection{Description}

The painted amphora (fig. 2; fig. 8) has a pinkish fabric (2.5 YR 8/3 Pink) covered by whitish slip (10 YR 8/2 White). The fabric is characterized by frequent minerals, limestone and mica, of little dimensions. The vase was about $40 \mathrm{~cm}$ tall. ${ }^{23}$ The rim is $16 \mathrm{~cm}$ wide. It has a raised lip slightly enlarged towards inside; shoulder is oblique with a rounded and slightly swollen shape. The profile of the body between the handles is straight. The vertical handles are ribbed with four shallow groves about $1 \mathrm{~cm}$ wide, forming a wavy profile, in an irregular ovoid section. ${ }^{24}$ The edges of the handles are characterized by four plastic quadrangular decorations.

The body has an overall a torpedo shape with a ring base. The foot has a diameter of $15.6 \mathrm{~cm}$, it has a raised, moulded and rounded profile; the bottom of $1 \mathrm{~cm}$ is flat. The form of its foot suggests both use for middle-short range trades or conservation. ${ }^{25}$

The amphora can be compared with a similar vessel from Kerkouane (North Africa), held in the Musée archéologique of the site ${ }^{26}$ (fig. 9), and with an amphora from Tharros (Sardinia) THT $77 / 146^{27}$ (fig. 10), nowadays in the Archaeological Museum of Cabras Giovanni Marongiu. The most suitable comparison is with the carinated amphorae found in the Tophet of Carthage. ${ }^{28}$

22 See Cintas 1950; Ciasca 1983, 617-622, fig. 1; Ramon Torres 1995, 242, T. 13.2.1.2, fig. 129; Docter 1997, 110-111, fig. 581 a-b; 135-139, fig. 581e; Toti 2002, 278, types 3, 5; 2003, 1205, pl. CCV:4.

23 Vecchio 2015, 140, n. 129, pl. 15, fig. 15, inv. n. 1672; Harden 1937, 59-89; Cintas 1950

24 This detail recalls Spanish (Ramon Torres 1995, 374, T. 2.1.1.2, fig. 25; 414, T. 5.2.3.2, fig. 64) and oriental prototypes (Gitin ed. 2015, 357, pl. 3.3.4.4).

25 "Carinated shoulder" amphorae with convex or pointed bottom, spread over Levant area in the $8^{\text {th }}$ century BC, were used for long trade (Lamon - Shipton 1939, 166; Bikai 1978, pl. VII:2-3; 1987, 43-44, pl. XXI:567, 575 Lehmann 1996, 430-431, pl. 69:379; Docter 1997, 110-111, fig. 581 a-b; 135-139, fig. 581 e; Hadjisavvas 2000, 1024-1025, 1052, n. 2; Doumet-Serhal 2003, 45, fig. 6). Moreover, this kind of vessel resembles oriental types used for conservation, like a phoenician storage jar (Gitin ed. 2015, 657, pl. 6.11.11.1) or a jar krater from En Jedi (Gitin ed. 2015, 357, pl. 33.4.4).

26 Cintas 1950, pl. XX:255. Motya and Kerkouane show some common features, such as their radial road system (Famà - Toti 1997, 113).

27 This specimen was an urn in the Tophet of Tharros (Cotza 1999, 54; Acquaro 1975, 213-220; 1976, 197-203; 1999, 40, fig. 1:9).

28 Harden 1937, fig. 4, class C, c type 1. 


\subsection{The "carinated shoulder" amphorae in the central Mediterranean: chronology and distribution}

Amphorae with "carinated shoulder" are attested from the $8^{\text {th }}$ century BC, until the 146 $\mathrm{BC}$ at Carthage, ${ }^{29}$ where they were used as urns in the Tophet ${ }^{30}$ and in the necropolis. ${ }^{31}$

Since the $7^{\text {th }}$ century BC, this kind of vase is also attested to other areas of North Africa $^{32}$ and to Sardinia, ${ }^{33}$ Sicily, ${ }^{34}$ Cyprus, ${ }^{35}$ and Iberian Peninsula, ${ }^{36}$ with the same funerary or cult destination.

Amphorae with "carinated shoulder" across centuries changed from an ovoid to a piriform profile ${ }^{37}$ with several variants ${ }^{38}$ (fig. 11), according with the stylistic trend in Phoenician pottery of lengthen the shapes, as testified by the morphological changes of painted oinochoai.

Three classes (A, B, C) identified by Donald B. Harden, between the Punic amphorae of the Precint of Tanit at Salammbô, are attested to Motya (fig. 11). Classes $\mathrm{A}^{39}$ and $\mathrm{B},{ }^{40}$ both ovoid with flared and enlarged rim, are differentiated by the handles, vertical in the first case and horizontal in the second. Class $\mathrm{C}^{41}$ has a torpedo shape, with a flat rim, carinated shoulders, and vertical handles. This last type also occurs at Nora, Ibiza, Villaricos and

Bechtold 2007, 345, n. 2059; Niemeyer et al. 2007, 345, ns. 2058-2059; Myres 1897, 159, fig. 12:14-15.

Harden 1937, 59-89; Ciasca 1983, fig. 1.

31 Lancel (éd.) 1982, 277, n. A.190.5, figs. 383-384; 287, n. A.191.6, figs. 401-402; 291, n. A.192.2, figs. 418419; 304, n. A.196.3, figs. 456-457; 311, n. A.183.5, figs. 480-481; Chelbi 1985, 99-100; Ciasca 1979, 215, n. 9, fig. 17.8, pl. LXXIV:6-7; Spanò Giammellaro 2000, 311, fig. 2.3; Bartoloni 2010, 65, figs. 72-73.

32 Gouraya (Cintas 1950, 137).

33 Acquaro 1999, 15-16; Whitaker 1921, 256, figs. 38:295-296; 72:297; 73:301; 77; Taramelli 1912, coll. 53-54, 101, fig. 16:3; Bartoloni 1983, 46-47, fig. 4:c; 1985, 250, fig. 5:b; 1990, 53-54, 79, fig. 12; 2000a, 115, 161, figs. 33, 99; Harden 1937, 59-89; Botto 2009, 231-232. Tharros, in Sardinia, had a central role in the distribution of this kind of vessel assimilating Carthaginian features and spreading it over in the Western Mediterranean. "Carinated shoulder" amphorae of this city are divided in slender, ovoid and crushed (Acquaro 1999, 15-16).

34 Bartoloni - Campanella 2000, 215; Bartolini 2010, 65; Spanò Giammellaro 2000, 311, 313, fig. 23; Ciasca 1983, 617-622, fig. 1; Spatafora 2010, 37, fig. 14.

35 Myres 1897, 134-173, figs. 12, 13:2, 14-15; Karageorghis 1967, 293, fig. 39; 1968, 283, fig. 47; Hadjisavvas 2012 , 12 , ns. $2-4$, fig. $5 ; 21$, n. 2 , fig. $10 ; 23$, n. 7 , fig. $11 ; 25-26$, n. 13 , fig. $12 ; 29$, n. 1 , fig. $14 ; 35$, ns. 11,18 fig. $16 ; 38$, ns. $2-3$, fig. $17 ; 40$, n. 35 , fig. $18 ; 64,66$, ns. $1-4$, fig. $34 ; 69$, n. $1 ; 71$, n. 17 , fig. $36 ; 75$, n. 2 , fig. $41 ; 80$, ns. $8-9$, fig. $43 ; 90$, n. 2 , fig. $47 ; 96$, n. 7 , fig. $53 ; 105,106,108$, ns. 2,7 , 9 , fig. $61 ; 117$, n. 2 , fig. 65 ; 125 , ns. $1-2$, fig. $71 ; 139$, ns. $2-3$, fig. $79 ; 158$, n. 2 , fig. $91 ; 161,163$, ns. 7 , 15 , fig. $95 ; 171,173$, ns. 5 , 9-10, 21, fig. 99; 193, n. 5, fig. 113; 197, n. 7, fig. 116

36 Niemeyer-Schubart 1976; González Prats 1982, 377, fig. 376, P-6022; 1989; Rodero Riaza 1983, 874-875, fig. 2:11.1; Aubet 1986, 25, fig. 8, n. 547; Aubet et al. 1999, 181; Gomez Bellar 2000, 178, fig. 3:1-2; Martin Ruiz 2004, 109, fig. 130; Ramon Torres 2011, fig. 4:66.

37 Cotza 1999, 49-50.

38 Harden 1937, 59-89.

39 Dated to the $8^{\text {th }}$ century BC: Harden 1927, 307, fig. 15; Cintas 1950, pl. XVII, n. 211

40 Dated to the $8^{\text {th }}$ century BC: Harden 1937, fig. 3, class B, f; Cintas 1950, pl. III:45; Whitaker 1921, 297, fig. 72.

41 Dated since the $7^{\text {th }}$ to the $5^{\text {th }}$ century BC: Harden 1937, fig. 3, class C, h; Cintas 1950, pl. III: 230 : VIII century B.C. Harden 1937, fig. 4, class C, a:e; Vecchio 2015, pl. 15, fig. 15, n. 129, inv. n. 1672: VII-VI century B.C Harden 1937, fig. 4, class C, a:f; Whitaker 1921, 301, fig. 77; 297, fig. 72; Cintas 1950, pl. XVIII:235. Harden 1937, fig. 4, class C, a:h; Whitaker 1921, 256, fig. 38; Cintas 1950, pl. XVIII:236. 
Cruz del Negro. ${ }^{42}$ These main classes are further subdivided in subtypes, based on shape variation, and are attested since $700 / 650 \mathrm{BC}$ to $350 / 300 \mathrm{BC}{ }^{43}$

Amphora MB.89.24/3 from Motya can be included in class C, c type $1,{ }^{44}$ according to the shape of grooved handles with plastic decorations, and it is dated to the end of the $4^{\text {th }}$ century BC, for its decoration, as we will see later in detail $(\$ 2.3)$.

$\mathrm{C}$ type 1 is usually painted in $\operatorname{red}^{45}(7.5 \mathrm{YR} 4 / 4 \mathrm{Light} \text { Red })^{46}$ on a white/pale yellow slip, ${ }^{47}$ and its decorative style belongs to the Red Monochrome Ware II (RMW II) style. ${ }^{48}$ RMW II is attested on amphorae, ${ }^{49}$ jugs,${ }^{50}$ oinochoai ${ }^{51}$ and gutti ${ }^{52}$ from the $6^{\text {th }}$ onwards, with major attestations between the end of $5^{\text {th }}$ and the $4^{\text {th }}$ century BC. In this mature phase, vegetal friezes and floral motifs are some of the most recurrent themes. ${ }^{53}$ In some cases they are polychrome. ${ }^{54}$

Both the decorative motifs and the pictorial style recall the Phoenician painting style, such as the funerary wall paintings, ${ }^{55}$ the stele ${ }^{56}$ and the ostrich eggs. ${ }^{57}$ As a general tendency, the Phoenician and Punic painted pottery shifts from the geometric patterns during the $8^{\text {th }}$ to $6^{\text {th }}$ century BC ${ }^{58}$ to the phytomorphic motifs in late $5^{\text {th }}-4^{\text {th }}$ century BC. ${ }^{59}$ Such change is also found in the amphorae with carinated shoulder at issue. The vegetable themes include

Harden 1937,73

These amphorae are found in the Tophet of Carthage, in the strata Tanit II (700/650 BC-350/300 BC)

44 Cintas 1950, pl. XIX:239.

45 Probably the red color evoked the image of blood and consequently of life and death. So, it had a symbolic and apotropaic value, and for this reason it was utilized on vases destined to cult or funerary contexts (Charles-Picard 1954)

46 Acquaro 1980, 173-179; Del Vais 2013, 3-64.

47 Motya (Cintas 1950, 77, n. 45=Harden 1937, fig. 3, e, class B; 129, n. 211=Harden 1927, fig. 15; 133, n. 232=Harden 1937, fig. 3, i, class C; n. 233=Harden 1937, fig. 3, h, class C; n. 234=Harden 1937, Tanit II, class C, a:e; 135 , n. 235=Harden 1937, Tanit II, class C, a:f; 236=Harden 1937, Tanit II, class C, a:h; n 239=Harden 1937, Tanit II, fig. 4, 1; 137, n. 245=Harden 1937, Tanit III, fig. 6, c; Carthage (Cintas 1950, 77, n. $45=$ Harden 1937, fig. 3, f, class B; 129, n. 211=Harden 1937, fig. 3, b, class A; 133, ns. 230-231=Harden 1937, fig. 3, h, class C, a; 153, n. 325=Harden 1937, fig. 3, j); Sardinia (Cintas 1950, 129, n. 217=Harden 1937, fig. 4, c, class A); Gouraya (Cintas 1950, 137, n. 254=Harden 1937, fig. 5, i, class F).

48 This style was radiated by Carthage, which borrowed the main plant motifs from coeval Greek ceramics and reused them in an original pictorial style: Nigro 2005, 727-737; Spagnoli 2019, 36-38.

49 Cintas 1950, pls. XVI:199, 200; XVII:211-212, 214, 216-219; XVIII:230, 232-235, 238 bis; XIX:239, 243 245, 248; XX:251-252, 254-255 quater; XXVII:325 a-h; XXVIII:325 bis, 326-332; XXIX:341, 345, 352-353; Del Vais 2013, 53, 63, figs. 12-22:SA 336, SA 31.

50 Cintas 1950, pl. VII:90-95, 97-98 bis. In addition, there are the specimens present in the Archaeological Collection of the Archiepiscopal Seminary of Oristano: Del Vais 2013, 45, 62, figs. 4-21:SA 194, SA 431, SA 191, SA 173, SA 171; 46, fig. 5: SA 184, SA 166, SA 163. Moreover, there is a globular flask (fig. 12:SA 285) of small size, that shows the same decoration.

51 Cintas 1950, pl. XIII:170-171; pl. XV-185-187, 189, 196

52 Cintas 1950, pl. XXXIII:371, 373, 376.

53 Together to the funerary parietal decoration and to the paintings on the handicrafts.

Red is replaced with black (gray or blue) or brown matt colors: Cotza 2005, 975-981.

As the tombs of Sidon, mostly decorated with vegetable motifs (Amadasi Guzzo 1988, 448).

Amadasi Guzzo 1988, 448-455; Vento 2000.

Savio 2004

$588^{\text {th }}-7^{\text {th }}$ century BC (Cotza 1999, 50-51; Acquaro 1999, 15-16) with an impoverishment of the decorations in the middle $7^{\text {th }}$ century BC (Pisano $\left.1996,135-136\right)$

59 Cotza 1999, 49-57. 
principally lotus flower, in frieze or at the center between two plants, myrtle leaves, ivy and fern, and palmette, as in the case of the amphora MB.89.24/3. ${ }^{60}$

\subsection{The painted decoration}

The vase belongs to the RMW II pictorial phase. The painted decoration is displayed on the shoulders and in the upper part of the body, specifically on the band between the handles (figs. 12-13).

On the shoulder the decoration is almost vanished, nevertheless a floral pattern sinuous raceme ending with a lobulated leave resembling that one onto ostrich egg s ${ }^{61}$ - can be recognized (figs. 12-13, 14b).

The principal decoration between the handles is composed by a frieze of four palmette (two on each side) with sixteen petals (figs. 12-13, 14a), ${ }^{62}$ ending in two volutes and encircled by a raceme.

Three drops, perhaps a triglyph (figs. 14c, 15-16), are painted with the tip pointing downwards on the upper part of the handle. The foot and the bottom of the vase are not decorated.

The presence at Motya of RMW II is emphasized on pithos MF.04.1273/4, discovered during the excavations of 2004 carried out by Sapienza Archaeological Expedition to Motya in the Area F- 'the Western Fortress', in an accessory structure of the cult building, dedicated to Astarte. ${ }^{63}$ It includes also two bowls: MC.12.4336/11 and N.12741 (159) 212, respectively from the Sacred Area of the Kothon and from the Sanctuary of Cappiddazzu. The latter was found during the excavations of 2017, and it is decorated with a line of drops, as those on handles of amphora MB.89.24/3. Another fragment of Punic amphora (MC.12.4428/6), from Area C South, shows a probable representation of stylized flowers. ${ }^{64}$ At least, during the excavation of 2019, a portion probably of an amphora was found (US. 7057), again in the Sanctuary of Cappiddazzu, and it was decorated with a red painted palmette, quite similar to the amphora MB.89.24/3.

Outside of Motya, other examples of palmette decoration are on an amphora from Carthage, ${ }^{65}$ showing a frieze of three vertical fern leaves. The vase from Kerkouane shows the same decorative syntax of the amphora from Motya. The main decoration is a frieze of heart-shaped leaves, probably ivy. Similarly, the "carinated shoulder" amphora from Tharros (THT 77/146), held in the Giovanni Marongiu Archaeological Museum of Cabras, can be compared with our amphora for its vegetal decoration depicted on the band between the handles.

The phytomorphic decoration recalls the parietal painting of the "Tomba dell'ureo" in the necropolis of Tuvixeddu (Cagliari) with the difference that in this case the palmette are circumscribed by a racemate terminating in a lotus flower. ${ }^{66}$ The palmette motif is widely

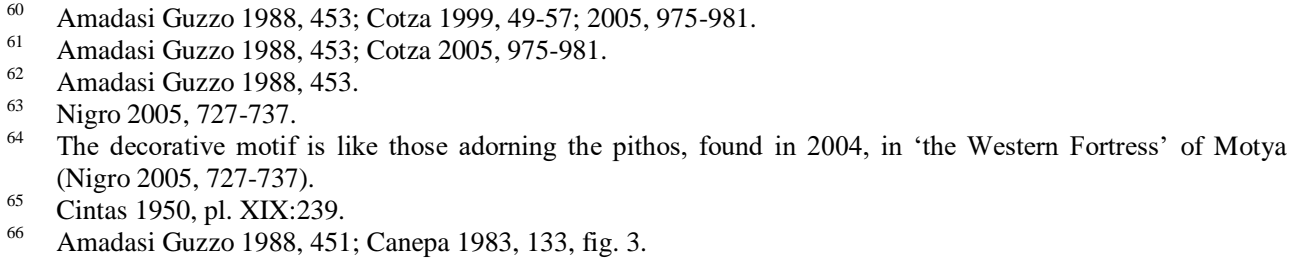


represented in Phoenician art, such as ivories, as exemplified by the ivories of Nimrud, ${ }^{67}$ metallurgy ${ }^{68}$ and stone relief. ${ }^{69}$ Nevertheless, it appears on Punic ceramic vases only at the end of the $5^{\text {th }}$ century BC-beginning of the $4^{\text {th }}$ century BC, probably under the influence of the Greek painting. ${ }^{70}$

\subsection{Chronology}

Basing on the finding context, the style of decoration, and the comparisons previously treated, the amphora from Area B can be dated to the mid of $4^{\text {th }}$ century BC. Its piriform profile, the rectilinear and moulded handles are characteristics of the late Phoenician-Punic production typical of this period. Vegetal decoration has its origin in the Phoenician decorative tradition. Nevertheless, iconographies of Punic painted pottery recall paintings on Greek vases of the $5^{\text {th }}$ and $4^{\text {th }}$ century $\mathrm{BC},{ }^{71}$ that influenced the Punic funerary parietal paintings and ostrich eggs spread over specially during those centuries.

\section{CONCLUSIONS}

The amphora with palmette decorative motif MB.89.24/3 from Motya stands out for its context of recovery and for the accurate painted frieze. Indeed, the vase was exceptionally found in a residential context, while usually similar specimens are discovered in cult or funerary contexts. Moreover, this kind of vase and this decorative style are quite rare in the island during the $4^{\text {th }}$ century BC.

Its retrieval in a public and residential quarters, like Area B, suggests a not exclusive use of this such vase in funerary or cult activities, at Motya, different than the other finding contexts testimony. ${ }^{72}$ At the same time, the few attestations together with the finding in ritual contexts, in other sites, like Carthage or Tharros, profiles it as a precious or symbolic good for an élite.

As it concerns the possible place of origin of the amphora, it seems quite possible to locate the atelier of production in Carthage, or in its neighborhoods, in the $4^{\text {th }}$ century BC, according to pictorial style. Indeed, in this period Carthage created a net of influences in the Center-Western Mediterranean. Western Sicily was included in this network. So, the contacts between the Sicilian city and the Punic city were prosperous and steady during the $4^{\text {th }}$ century BC so as to allow the circulation of products and craftsmen, but also models, wealthy goods, and fashions. ${ }^{73}$

In this way, MB.89.24/3 testifies the existence of a belated occupation of the island during the $4^{\text {th }}$ century $\mathrm{BC}^{74}$ and the inclusion of Motya in the Carthaginian trades. Moreover, the amphora provides additional information about the Phoenician high-status

67 Uberti 1988, 406-408, 413, 418.

68 Karageorghis 1988, 159.

69 As shown by the stele from Carthage: see Alaoui 1954, CIS 4044, pl. XXX:4; D’Andrea 2018, pl. XIV.

70 Ciasca 1983, 621-622; Amadasi Guzzo 1988, 451-453; Cotza 1999, 51.

71 As shown by Carthage's recovery of pictorial models from the Attic black-figure vases, from the urns of Alexandria's necropolis and from Hadra and Sciabti's hydriae (Guerrini 1964).

72 Cintas 1950; Vecchio 2015, 140, n. 129, pl. 15, fig. 15, inv. n. 1672; Whitaker 1921, 256, figs. 38:295-296; 72:297; 73:301; 77.

73 Acquaro 1980, 173-179; Del Vais 2013, 3-64; Spagnoli 2019, 36-38.

74 Tusa 1967, 85-95. 
class, its mode and appreciation for precious goods from abroad and for Greek stylistic elements, included in own production.

\section{REFERENCES}

ACQUARO, E.

1975 Tharros II. Lo scavo del 1975: Rivista di Studi Fenici 3 (1975), pp. 213-220.

1976 Tharros III. Lo scavo del 1976: Rivista di Studi Fenici 4 (1976), pp. 197-203.

1980 Tharros: un centro dell'antico Mediterraneo: Atti Convegno sulla Preistoria - Protostoria - Storia della Daunia. San Severo, 23-25 novembre 1979, San Severo 1980, pp. 173-179.

1999 La ceramica di Tharros in età fenicia e punica: documenti e prime valutazioni: A. GONZÁlEZ Prats (ed.), La cerámica fenicia en Occidente: centros de producción y áreas de comercio. Actas del I Seminario Internacional sobre Temas Fenicios, Guardamar del Segura 1997, Alicante 1999, pp. 13-40.

AuBET, M.E

1986 Los fenicios en España: estado de la cuestión y perspectivas: G. DEL OLMO LETE - M.E. Aubet (eds.), Los Fenicios en la Peninsula Iberica (Aula Orientalis 3,3), Sabadell 1986 pp. 9-38.

Aubet, M.E. - Carmona, P. - Curiè, E. - Delgado, A. - Fernández, A. - PÁrraga, M.

1999 Cerro del Villar - 1. El asentamiento fenicio en la desembocadura del rio Guadalhorce y su interracción con el hinterland (Arqueologia Monografias 5), Sevilla 1999.

BARTOLONI, P.

1983 Studi sulla ceramica fenicia e punica di Sardegna, Roma 1983.

1985 Monte Sirai 1984. La necropoli (campagne 1983 e 1984): Rivista di Studi Fenici 13 (1985), pp. 247-263

2010 Antonella Spanò e gli studi sulla ceramica fenicia di Sicilia: R. DolCE (ed.), Giornata di studi in onore di Antonella Spanò, Palermo 2008, Palermo 2010, pp. 55-85.

BARTOLONI, P. - CAMPANELLA, L.

2000 La ceramica fenicia di Sardegna. Dati, problematiche, confronti. Atti del Primo Congresso Internazionale Sulcitano, Sant'Antioco, 19-21 Settembre 1997 (Collezione di Studi Fenici 40), Pisa - Roma 2000.

BECHTOLD, B.

2007 Die phönizisch-punische Gebrauchskeramik der archaischen bis spatpunischen Zeit: H.G. Niemeyer - R.F. Docter - K. Schmidt - B. Bechtold (Hrsg), Kartago. Die Ergebnisse der Hamburger Grabung unter dem Decumanus Maximus (Hamburger Forschungen zur

BIKAI, P.M. Archaologie 2), Mainz am Rhein 2007, pp. 327-431.

1978 The Pottery of Tyre, Warminster 1978.

Bотто, $\mathrm{M}$.

2009 La ceramica da mensa e da dispensa fenicia e punica: Nora I (2009), pp. 97-237.

CANePa, M.

1983 La tomba «dell'ureo» nella necropoli di Tuvixxeddu-Cagliari: Dialoghi di archeologia CHARLES-PICARD, G.

$1954 \quad$ Les religions de l'Afrique antique, Paris 1954.

CHelbi, F.

1985 Découverte d'un tombeau archaïque à Junon (Carthage): Reppal 1 (1985), pp. 95-119. 
CIASCA, A.

1979 Scavi alle mura di Mozia (Campagna 1978): Rivista di Studi Fenici 7 (1979), pp. 207-227.

1983 Note moziesi: Atti del I Congresso Internazionale di Studi Fenici e Punici (1983), pp. 617-622.

CINTAS, P.

$1950 \quad$ Céramique punique, Tunis 1950.

COTZA, E.

1999 A Study on Painted Vegetable Patterns on Tharros Punic Pottery: G. PISANO (ed.), Phoenicians and Carthaginians in the Western Mediterranean (Studia Punica 12), Roma 1999, pp. 49-57.

2005 La pittura nella ceramica punica: il caso di Tharros: A. SPANò GiAmMELlaRo (ed.), Atti del V Congresso Internazionale di Studi fenici e punici (Marsala-Palermo, 2-8 dicembre 2000), Palermo 2005, pp. 975-981.

D'ANDREA, B

2018 Bambini nel limbo. Dati e proposte interpretative sui tofet fenici e punici, Roma 2018.

DEL VAIS, C.

2013 Le ceramiche fenicie e puniche della Collezione archeologica del Seminario Arcivescovile di Oristano: I. SANNA (ed.), Il seminario Arcivescovile di Oristano. Studi e ricerche sul Seminario (1712-2012), Volume II, Oristano 2013, pp. 3-64.

DOCTER, R.F.

1997 Archaische Amphoren aus Karthago und Toscanos. Funspektrum und Formentwicklung. Ein Beitrag zur phöinizischen Wirtschaftsgeschichte, Amsterdam 1997.

DOUMET-SERHAL, C.

2003 Jars from the First Millennium BC at Tell Rachidieh (south of Tyre): Phoenician Cinerary Urns and Grave Goods: Archaeology and History in Lebanon 17 (2003), pp. 42-51.

FAMÀ, M.L.

1990 Testimonianze del VII secolo a.C. nell'abitato di Mozia: Sicilia Archeologica 72 (1990), pp. 13-18.

1995 Appunti per lo studio dell'urbanistica a Mozia: M. H. FANTHAR - M. GHAKI (éds.), Actes du III Congrès International des Études Phéniciennes et Puniques, Tunis, 11-16 novembre 1991, Tunis 1995, pp. 422-434.

1997 Gli scavi recenti nell'abitato di Mozia: nuove prospettive di indagine alla luce dei primi risultati della ricerca: A. CORRETTI (a cura di), Atti delle Seconde Giornate Internazionali di Studi sull'Area Elima, Gibellina, 22-26 ottobre 1994, Pisa - Gibellina 1997, pp. 643654.

FAMÀ, M.L. (ed.)

2002 Mozia. Gli scavi nella "Zona A" dell'Abitato (Collana di Archeologia del Centro Internazionale di Studi Fenici, Punici e Romani, Comune di Marsala, 1), Bari 2002.

FAMÀ, M.L. - TOTI, M.P.

1997 Mozia: gli scavi nella “Zona E” dell'abitato: H. P. IsLER - D. KACH - O. STEFANI (Hrsg.), Wohnbauforschung in Zentral - und Westsizilien. Sicilia Occidentale e Centromeridionale: ricerche archeologiche nell'abitato, Zürich, 28 Februar - 3 März 1996, Zürich 1997, pp. 113-123.

Gallo, E.

2018 Due pesi di piombo dalla Casa del pozzo quadrato a Mozia: Folia Phoenicia: an GiTiN, S. (ed.) international journal 2 (2018), pp. 35-41.

2015 The Ancient Pottery of Israel and its neighbors from the Iron Age through the Hellenistic Period, Jerusalem 2015. 


\section{GONZÁLEZ Prats, A.}

1982 La Peña Negra IV. Excavaciones de 1980-81 en el Sector VII de la ciudad orientalizante: Noticiaro Arquelògico Hispánico 13 (1982), pp. 109-418.

1989 Dos bronces fenicios de la colecciòn Candela: Aportaciòn al conocimiento de la orfebreria e iconografia orientalizante de la Peninsula Ibèrica: M.E. AubET (ed.), Tartessos. Arqueologia Protohistòrica Bajo Guadalquivir, Sabadell 1989, pp. 411-430.

GUERRINI, L

1964 Vasi di Hadra. Tentativo di sistemazione cronologica di una classe ceramica, Roma 1964.

HADJISAVVAS, S.

2000 Recent Phoenician discoveries on the island of Cyprus: Actas del IV Congreso Internacional de Estudios Fenicios y Púnicos: Cádiz, 2 al 6 de octubre de 1995, vol IV, Cádiz 2000 pp. 1023-1034.

2012 The Phoenician Period Necropolis of Kition, vol. I, Nicosie, Cryprus 2012

HARDEN, D.B.

1927 Punic Urns from the Precinct of Tanit at Carthage: American Journal of Archaeology 31 (1927), pp. 297-310.

1937 The Pottery from the Precinct of Tanit at Salammbô. Carthage: Iraq IV/1 (1937), pp. 5989.

KARAGEORGHIS, V.

1967 Chronique des fouilles et découvertes archéologiques à Chypre en 1966: Bullettin de Corrispondance Hellénique 91 (1967), pp. 275-370.

1968 Chronique des fouilles et découvertes archéologiques à Chypre en 1967: Bullettin de Corrispondance Hellénique 91 (1968), pp. 261-358.

1988 Chronique des fouilles et découvertes archéologiques à Chypre en 1987: Bullettin de Corrispondance Hellénique 112 (1988), pp. 793-855

LAMON, R.S. - SHIPTON, G.M.

1939 Megiddo I. Seasons of 1925-34: Strata I-V (Oriental Institute Publications 42), Chicago 1939.

LANCEL, S. (éd.)

1982 Byrsa II. Mission archéologique française à Carthage. Rapports préliminaires sur les fouilles 1977-1978. Niveaux et vestiges puniques (Collection de l'École Française de Rome 41), Rome 1982.

LEHMANN, G.

1996 Untersuchungen zur späten Eisenzeit in Syria und Libanon. Stratigraphie und Keramikformen zwischen ca. 720 bis 300 v. Chr. (Altertumskunde des Vorderen Orients 5), Münster 1996.

MARTIN RUIZ, J.A.

$2004 \quad$ Los Fenicios en Andalucia, Sevilla 2004

MYRES, J.L.

1897 Excavations in Cyprus in 1894: Journal of Hellenic Studies 17 (1897), pp. 134-173.

NiEMEYER, H.G. - SCHUBART, H.

1976 Trayamar. Los ipogeo fenicios y el asentamiento en la desembocadura del rio Algarrobo (Excavaciones Arquelógicas en España 90), Madrid 1976.

Niemeyer, H.G. - Ugent, R.D. - Schmidt, K. - BeChtold, B.

2007 Karthago. Die Ergebnisse der Hamburger Grabung unter dem Decumanus Maximus, Mainz 2007. 
NiGRO, L.

2005 Un pithos dipinto dalla Fortezza Occidentale di Mozia: Scienze delle Antichità 12 (20042005), pp. 727-737.

2018 La Sapienza a Mozia 2010-2016: il primo insediamento fenicio, l'area sacra di Baal e Astarte, il tofet, la necropoli, l'abitato, i nuovi scavi alle mura - Una sintesi: Folia Phoenicia: an international journal 2 (2018), pp. 253-277.

NigRo, L. (ed.)

2004 Mozia - X. Zona C. Il Kothon. Zona D. Le pendici occidentali dell'Acropoli. Zona F. La Porta Ovest. Rapporto preliminare della XXII campagna di scavi - 2002 condotta congiuntamente con il Servizio Beni Archeologici della Soprintendenza Regionale per $i$ Beni Culturali e Ambientali di Trapani (Quaderni di Archeologia Fenicio-Punica I), Roma 2004.

2005 Mozia - XI. Zona C. Il Tempio del Kothon. Rapporto preliminare delle campagne di scavi XXIII e XXIV (2003-2004) condotte congiuntamente con il Servizio Beni Archeologici della Soprintendenza Regionale per i Beni Culturali e Ambientali di Trapani (Quaderni di Archeologia Fenicio-Punica II), Roma 2005.

2007 Mozia - XII. Zona D. La "Casa del sacello domestico", il "Basamento meridionale" e il Sondaggio stratigrafico I. Rapporto preliminare delle campagne di scavi XXIII e XXIV (2003-2004) condotte congiuntamente con il Servizio Beni Archeologici della Soprintendenza Regionale per i Beni Culturali e Ambientali di Trapani (Quaderni di Archeologia Fenicio-Punica III), Roma 2007.

2010 Alle origini di Mozia: stratigrafia e ceramica del Tempio del Kothon dall'VIII al VI secolo a.C.: L. NigRo (ed.), Mozia and the Phoenician Repertoire between the Levant and the West, $9^{\text {th }}-6^{\text {th }}$ century BC. Proceedings of the International Conference held in Rome, $26^{\text {th }}$ February 2010 (Quaderni di Archeologia Fenicio-Punica V 2010), pp. 276-318.

2011 Mozia - XIII. Zona F. La Porta Ovest e la Fortezza Occidentale. Rapporto preliminare delle campagne di scavi XXIII-XXVII (2003-2007) condotte congiuntamente con il Servizio Beni Archeologici della Soprintendenza Regionale per $i$ Beni Culturali e Ambientali di Trapani (Quaderni di Archeologia Fenicio-Punica VI), Roma 2011.

2012 Scavi e restauri dell’Università di Roma "La Sapienza" a Mozia, 2007-2009: il Tempio del Kothon, il Temenos Circolare, il Sacello di Astarte e il Tofet: C. Ampolo (ed.), Sicilia occidentale. Studi, rassegne, ricerche. Atti delle settime giornate di studi sull'area elima e la Sicilia occidentale nel contesto mediterraneo, Erice 12-15 ottobre 2009 (Seminari e Convegni 29), Pisa 2012, pp. 210-218.

NigRo, L. - SPAGNOLI, F.

2017 Landing on Mozia. The Earliest Phoenician Settlement of the 8th century BC and the creation of a West Phoenician Cultural Identity in the excavations of Sapienza University of Rome - 2012-2016 (Quaderni di Archeologia Fenicio-Punica/Colour Monograph 04), Rome 2017.

PisANO, G. (ed.)

1996 La pittura e il colore nell'Occidente punico: un'eredità di "tradizione" fenicia. Nuove ricerche puniche in Sardegna: Studia Punica 11 (1996), pp. 125-143.

RAMON TORRES, J.

1995 Las ánfora fenicio-púnicas del Mediterráneo central y occidental (Instrumenta 2), Barcelona 1995.

2011 La ceràmica fenicia del Mediterràneo extremo-occidental y del Atlàntico (s. VIII - 1r. 1/3 del VI a.C.). Problemas y perspectivas actuales: L. Nigro (ed.), Motya and the Phoenician Ceramic Repertoire between the Levant and the West- $9^{\text {th }}-6^{\text {th }}$ century. Proceedings of 
the International Conference held in Rome, $26^{\text {th }}$ February 2010 (Quaderni di Archeologia Fenicio-Punica V), Roma 2011, pp. 151-171.

RODERO RIAZA, A.

1983 Museo Arqueológico Nacional. Colección de cerámica púnica de Ibiza, Madrid 1983.

SAVIO, G.

2004 Le uova di struzzo dipinte nella cultura punica, Madrid 2004.

SPAGNOLI, F.

2019 La ceramica dipinta fenicia e punica a Mozia. Le produzioni e i motivi decorativi (VIII-IV secolo a.C.) (Quaderni di Archeologia Fenicio- Punica VIII), Roma 2019.

SPANÒ GIAMMELlaRo, A

2000 La ceramica fenicia della Sicilia: P. BARTOLONI - L. CAMPANELla (edd.), La ceramica fenicia di Sardegna. Dati, problematiche, confronti. Atti del Primo Congresso Internazionale Sulcitano, Sant'Antioco, 19-21 settembre 1997 (Collezione di studi fenici, 40), Pisa - Roma 2000, pp. 303-331.

SPATAFORA, F

2010 La necropoli di Panormos: F. SPATAFORA - S. VASSALLO (edd.), L'ultima città: rituali e spazi funebri nella Sicilia nord-occidentale di Età arcaica e classica. Catalogo della mostra, Palermo, Convento della Magione, 30 aprile 2010, Palermo 2010, pp. 31-50.

TARAMELLI, A.

1912 La necropoli punica di Predio Ibba a S. Avendrace, Cagliari (scavi del 1908)

TотI, M.P. (Monumenti Antichi XXI), Roma 1912.

2002 Anfore fenicie e puniche: M.L. FAMÀ (ed.), Mozia. Gli scavi della "Zona A" dell'Abitato, Bari 2002, pp. 275-304.

2003 Le anfore fenicie e puniche della collezione Whitaker (Museo G. Whitaker, Isola di Mozia): A. CORRETTI (a cura di), Quarte Giornate Internazionali di Studi sull'Area Elima. Atti, III, Pisa 2003, pp. 1203-1214.

TUSA, V.

1967 Mozia dopo il 397 a.C., Mozia III (1967), pp. 85-95.

VECCHIO, P.

2002 La ceramica comune: M.L. FAmÀ (ed.), Mozia. Gli scavi della "Zona A" dell'Abitato, Bari 2002, pp. 203-273.

2015 La ceramica comune fenicio-punica della Collezione Whitaker di Mozia. Necropoli e tofet, Roma 2015.

VENTO, M.

$2000 \quad$ Le stele dipinte di Lilibeo, Marsala 2000.

WHITAKER, J.I.S.

1921 Mozia. A Phoenician Colony in Sicily, London 1921. 


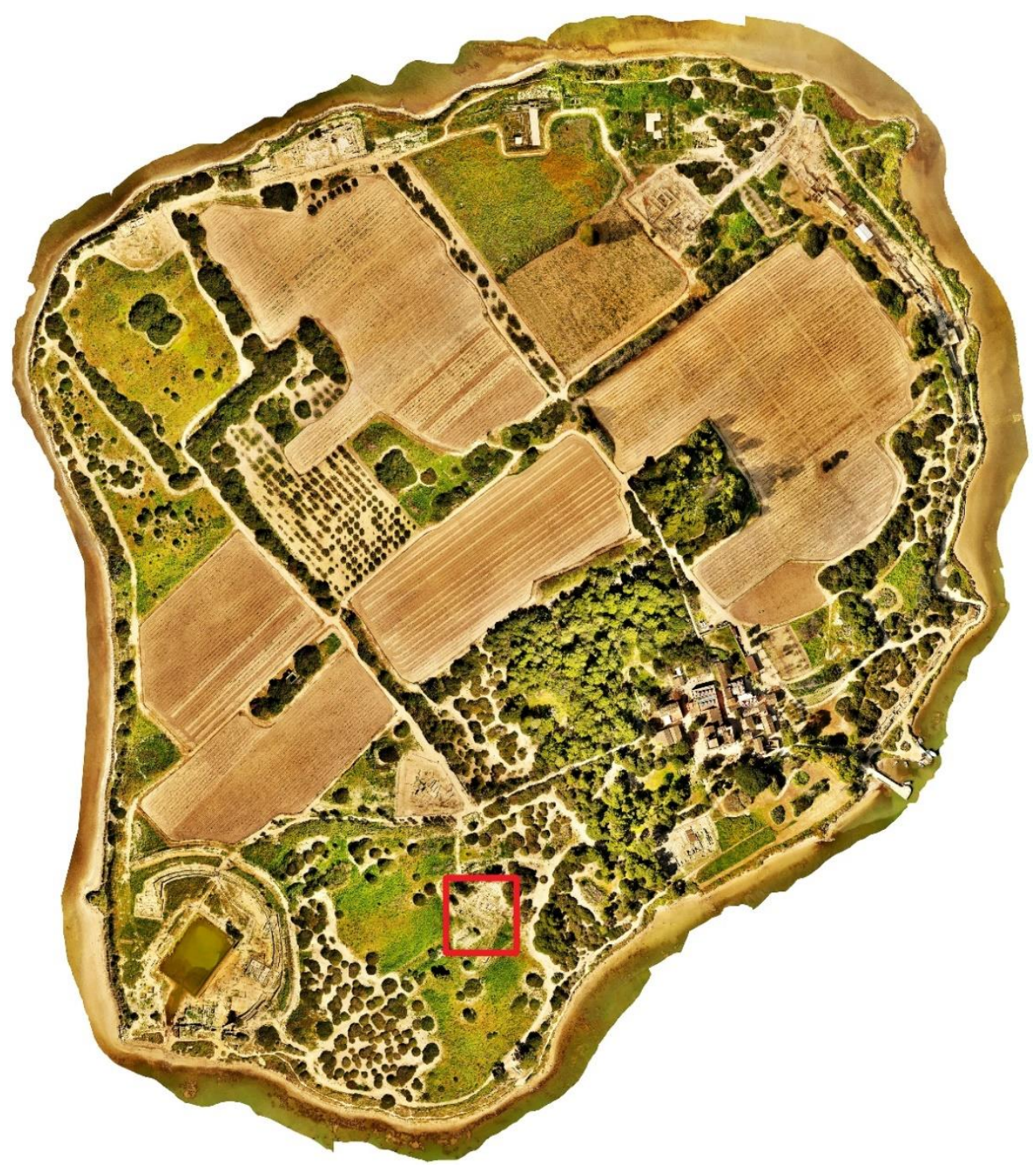

Fig. 1 - Map of Motya with the Area B highlighted in red. 


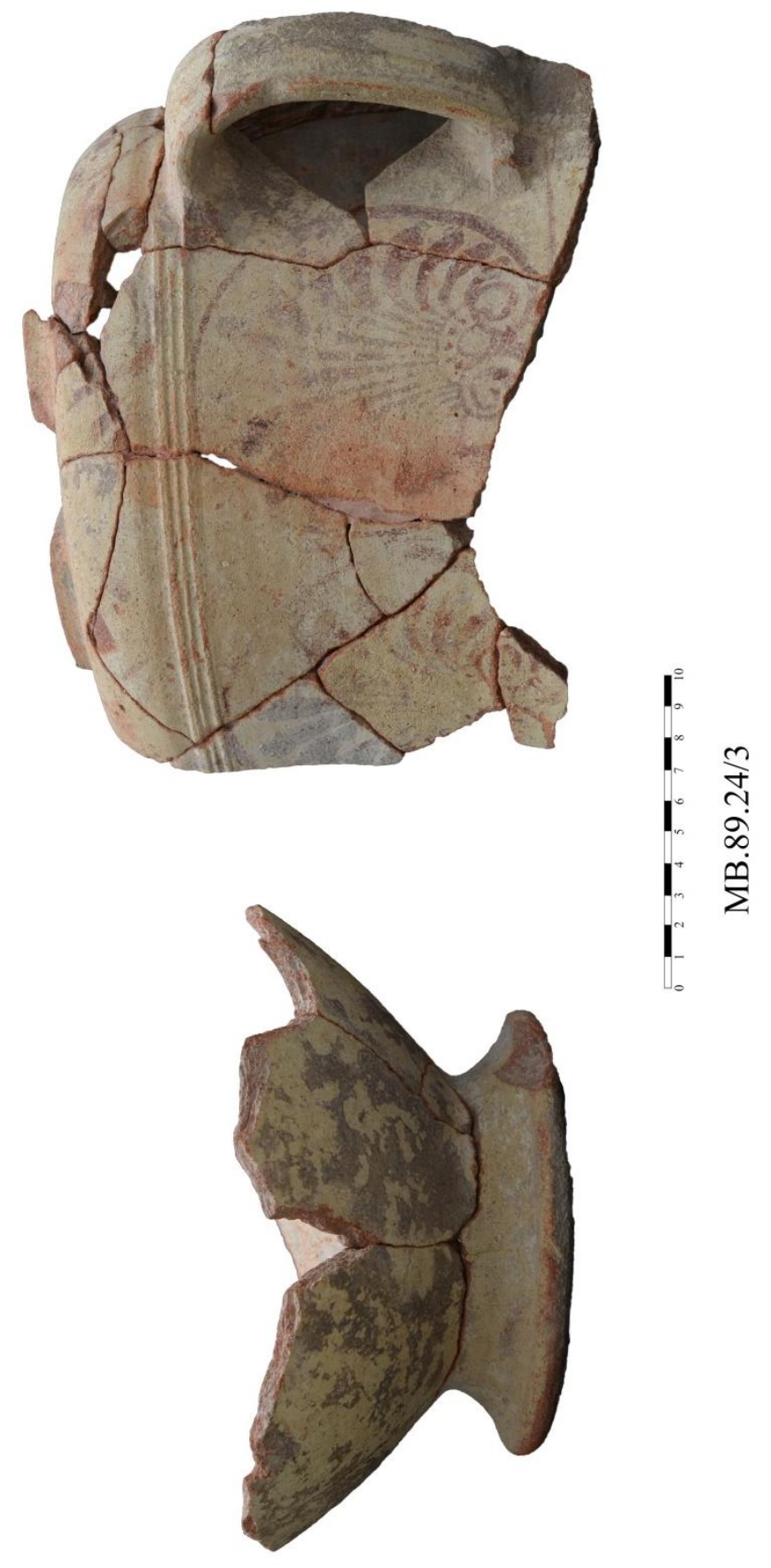

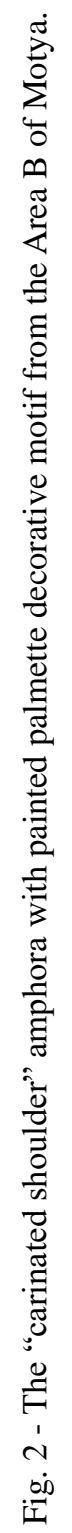




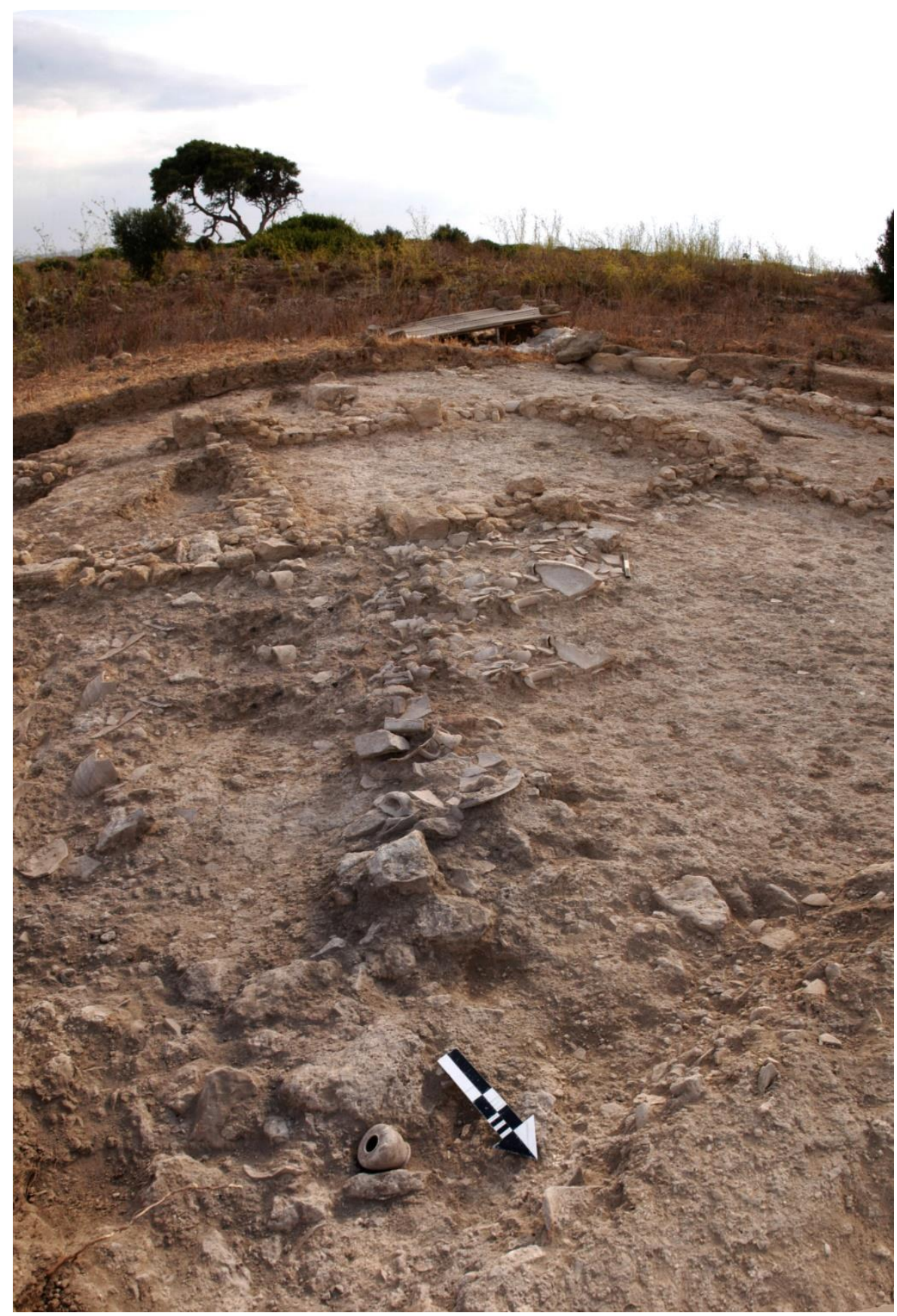

Fig. 3 - View of the Area B of Motya. 


\section{US 24}

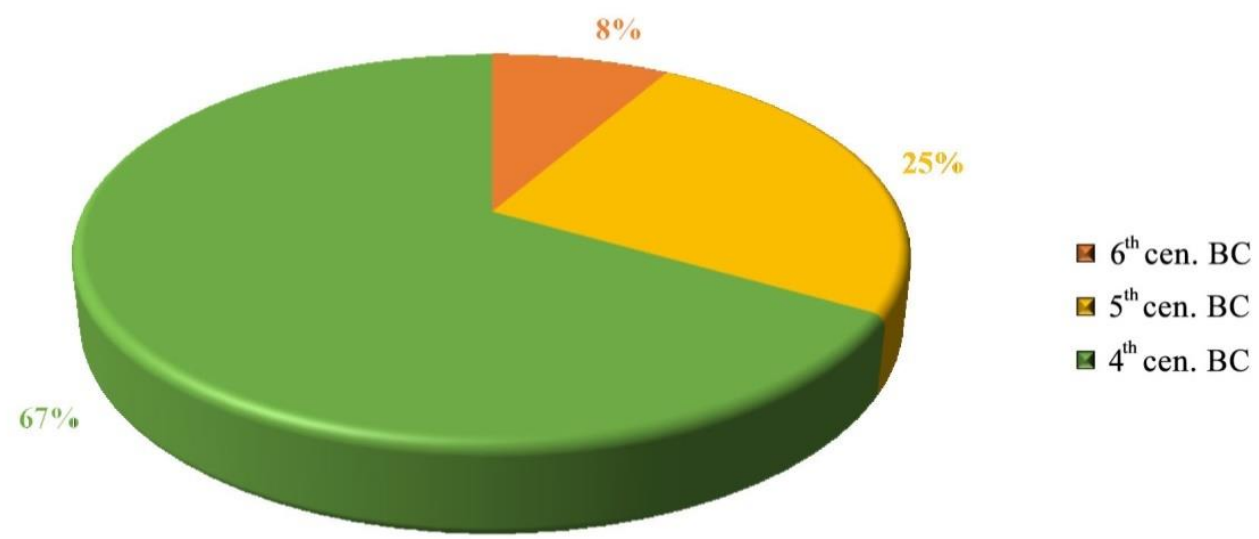

Fig. 4 - Pie chart of the ceramic classes in the repertoire of the Area B. The common Punic ceramic constitutes the majority.

\section{Ceramic classes}

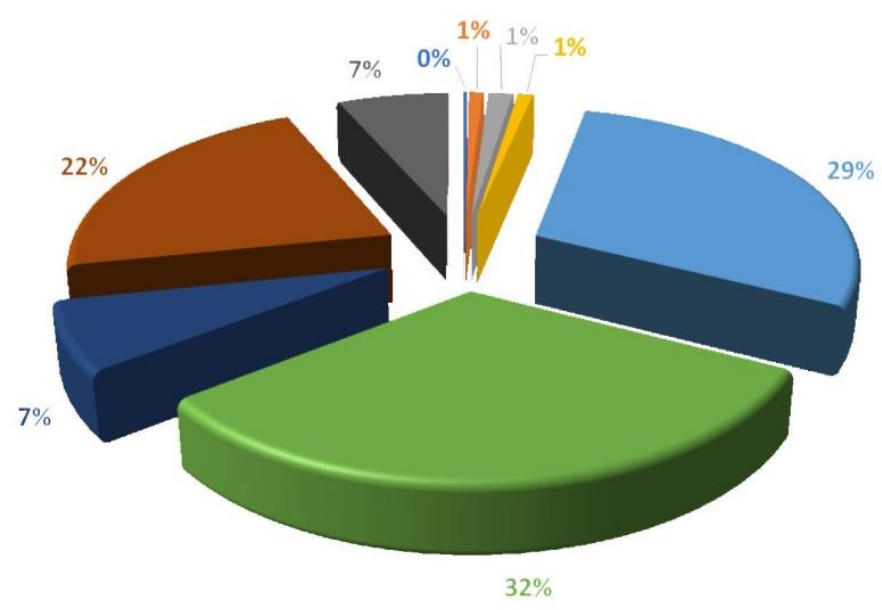

aCorinthian

aRed Slip

国Black or Red figure

gPainted

口Attic

口Simple Ware

aspecial Uses

QTransport

Impato Ware

Fig. 5 - Pie chart of the ceramic classes of the US 24. 

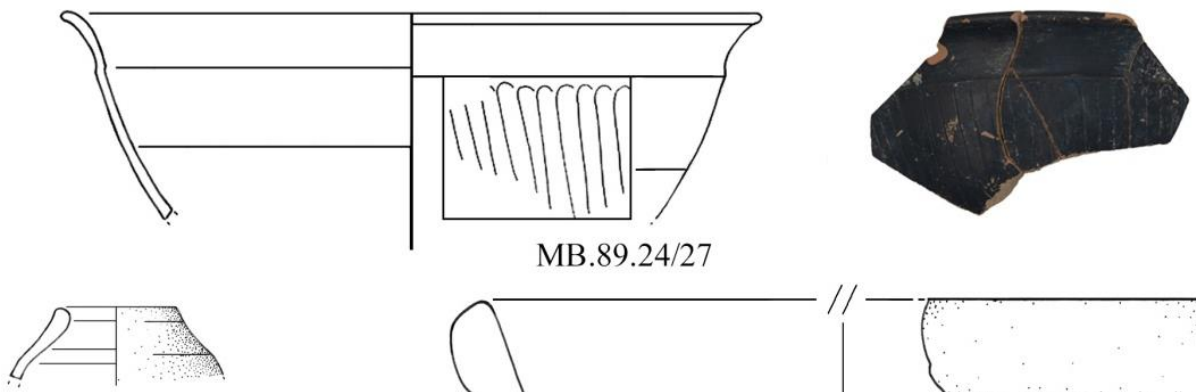

MB.89.24/25
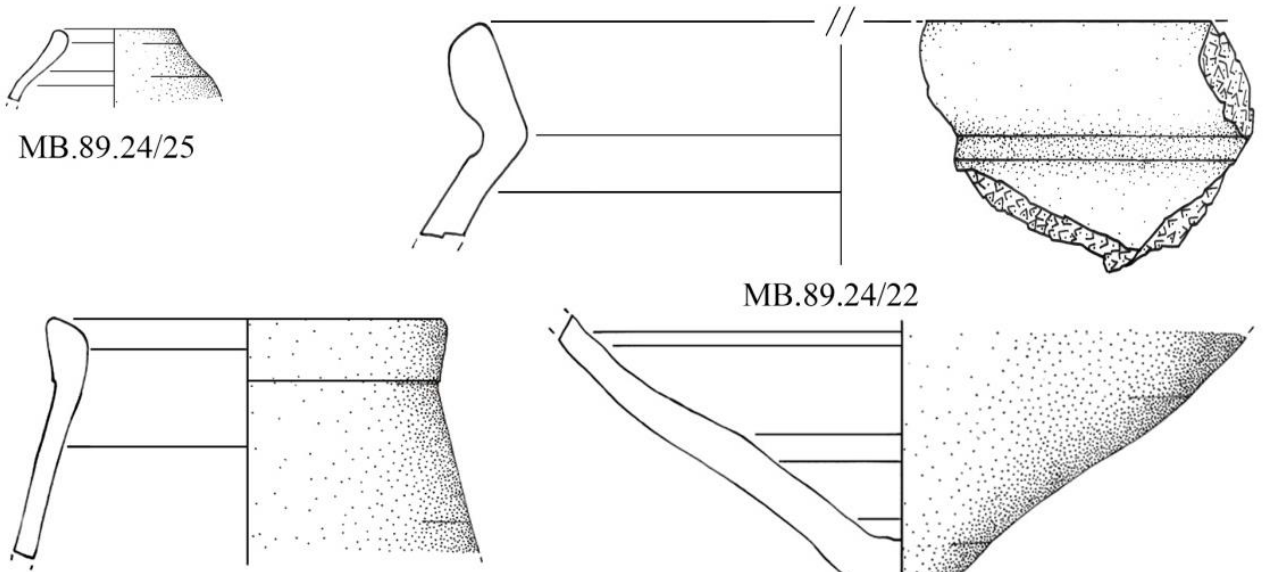

MB.89.24/22

MB.89.24/25
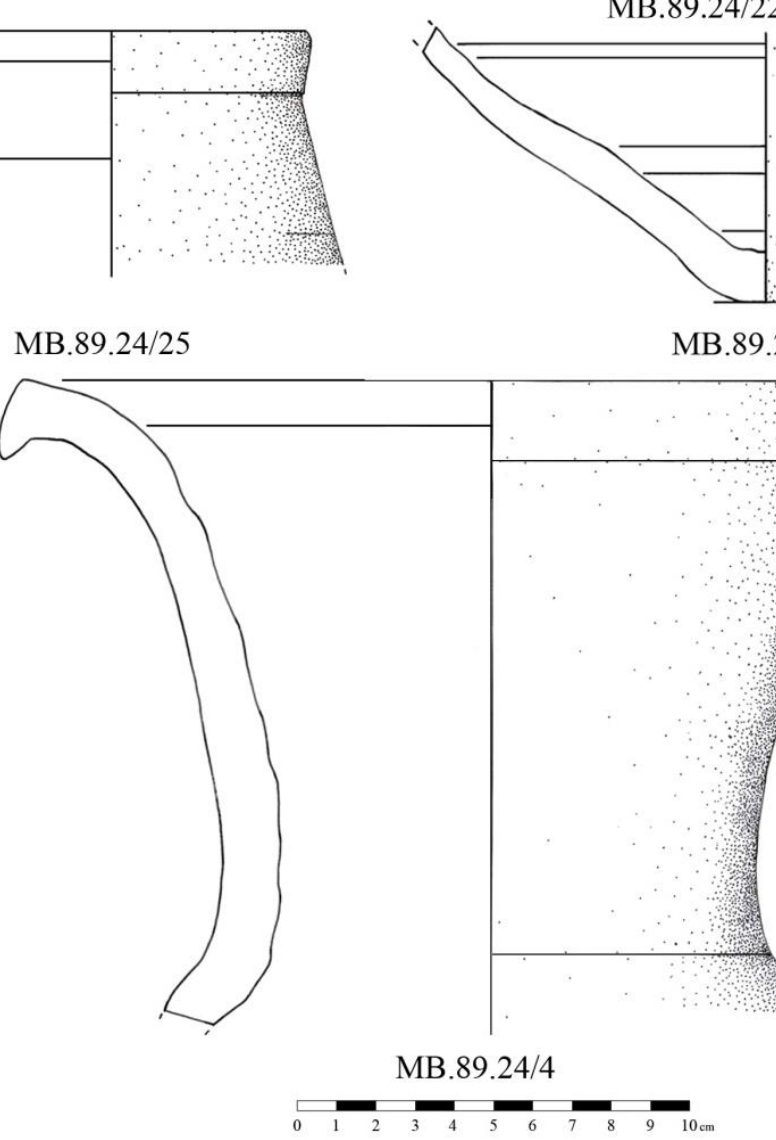

Fig. 6 - Attic pottery, special use pottery and the amphorae collected in US 24. 


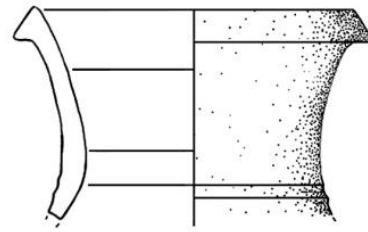

MB.89.24/20

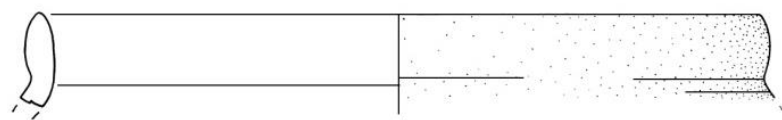

MB.89.24/26

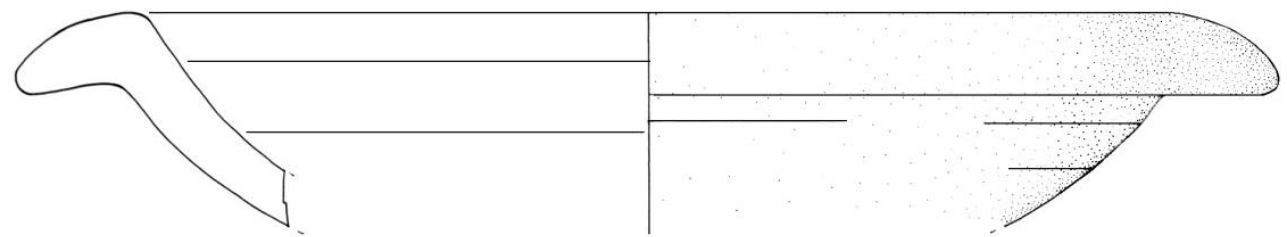

MB.89.24/24

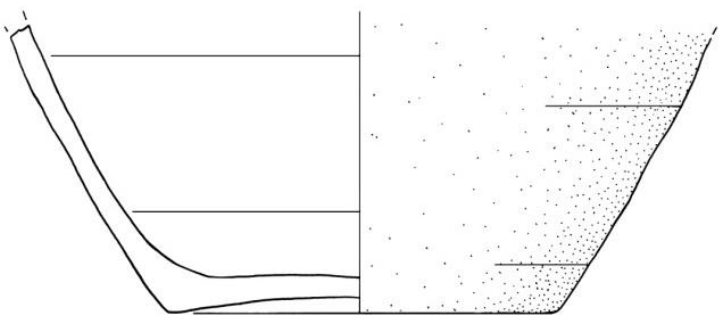

MB.89.24/23

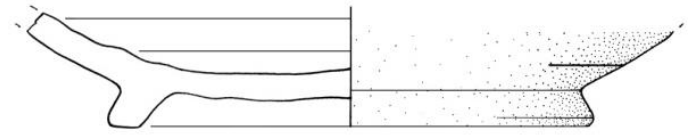

MB.89.24/21

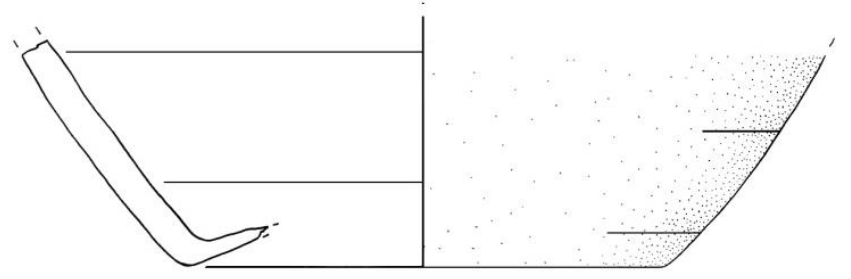

MB.89.24/9

\begin{tabular}{llllllllllll}
\hline 0 & 1 & 2 & 3 & 4 & 5 & 6 & 7 & 8 & 9 & $10 \mathrm{~cm}$
\end{tabular}

Fig. 7 - Simple Ware collected in US 24. 


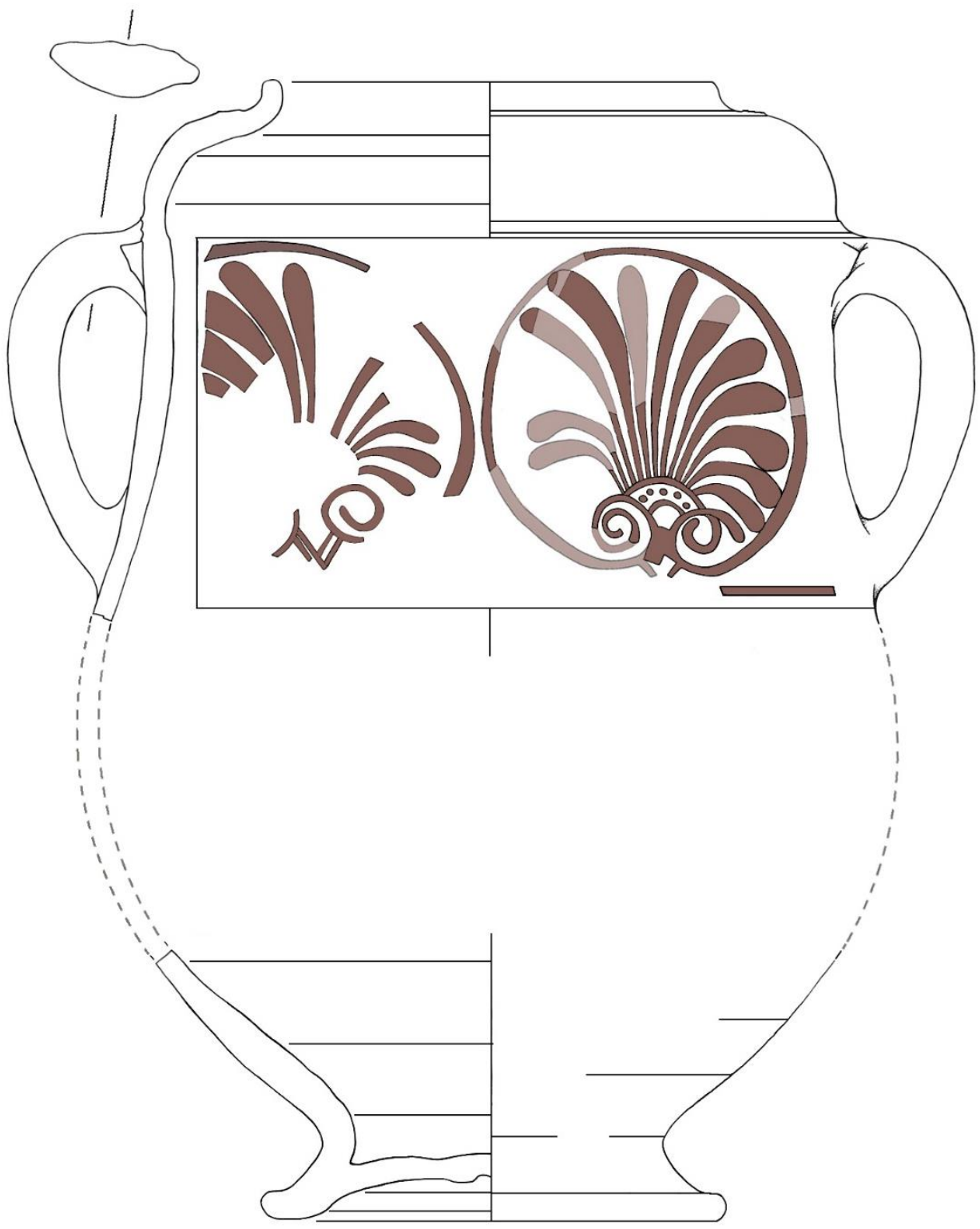

MB.89.24/3 (scale 1:3)

$\begin{array}{llllllllll}0 & 1 & 2 & 3 & 4 & 5 & 6 & 7 & 8 & 9\end{array}$

Fig. 8 - The amphora MB.89.24/3. 
Fig. 9 - The "carinated shoulder" amphora of class C, from the Musée archéologique de Kerkouane, Tunisia.

Fig. 10 - The "carinated shoulder" amphora of class C, from the Archaeological Museum of Cabras Giovanni Marongiu, Sardinia.

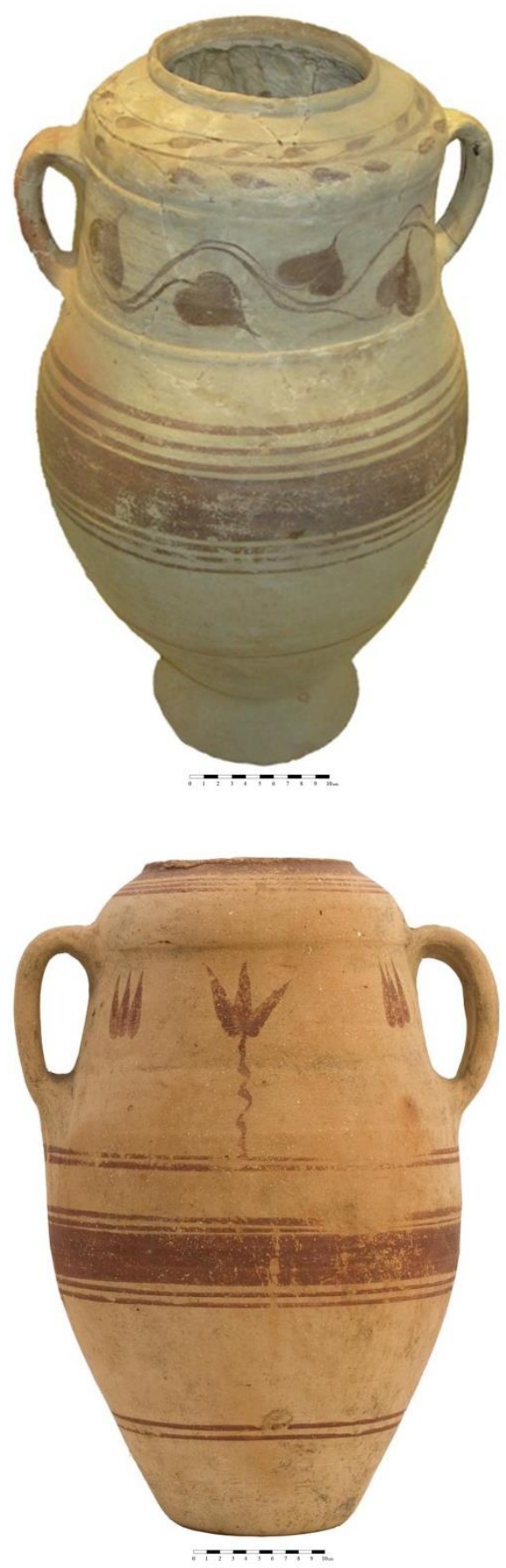




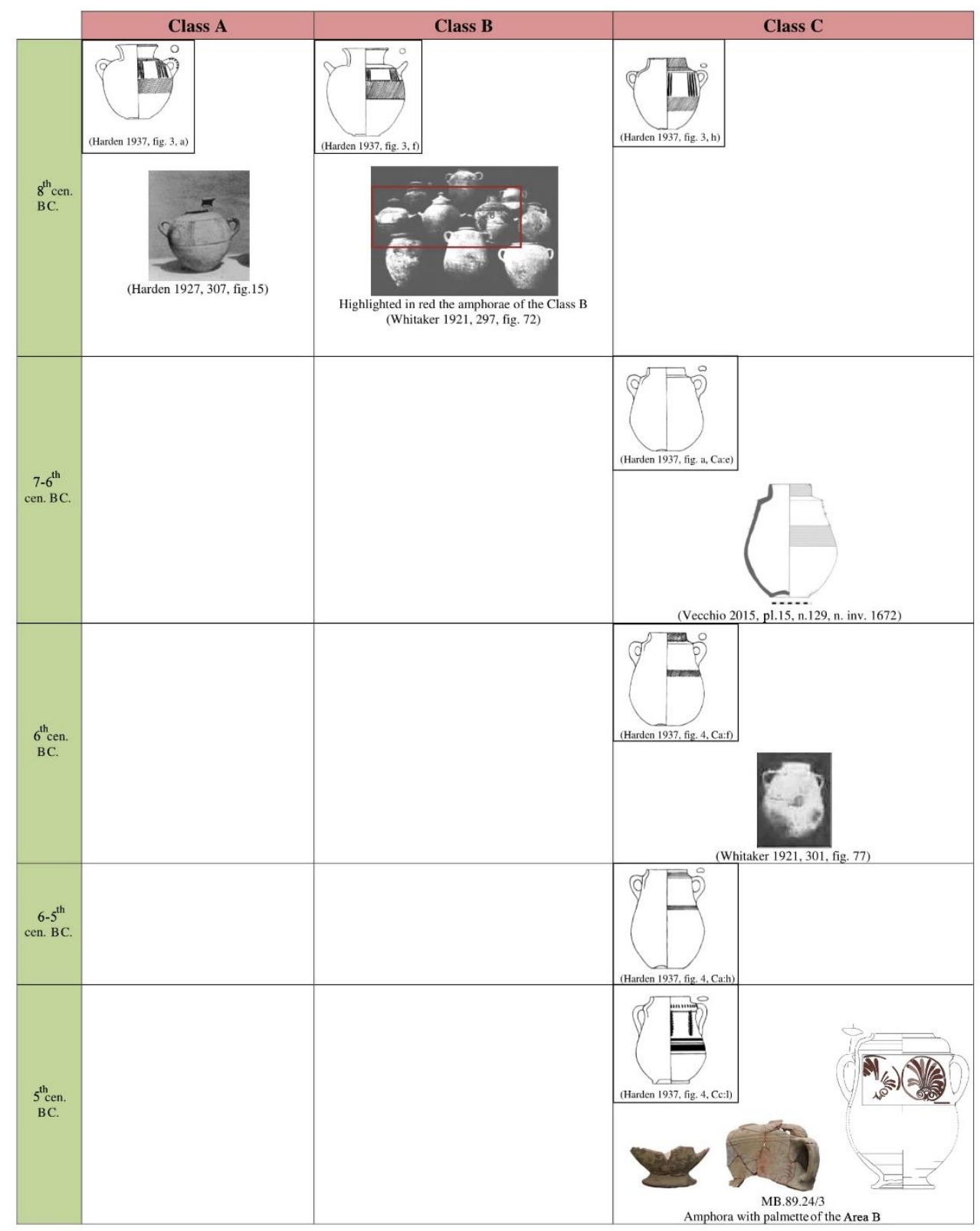

Fig. 11 - Table showing different types of the "carinated shoulder" amphorae found at Motya, based on Harden's classification. 


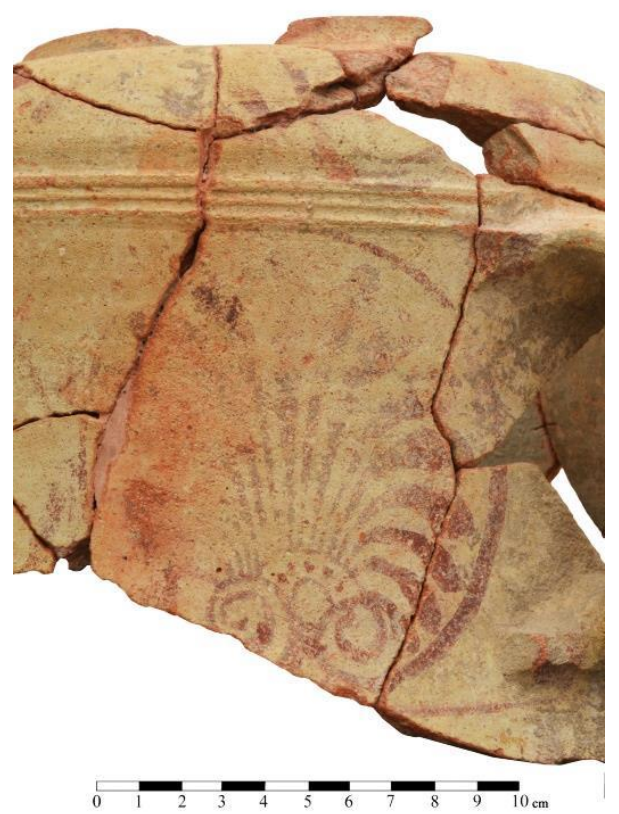

Fig. 12 - Detail of the decoration of the amphora of the Area B.

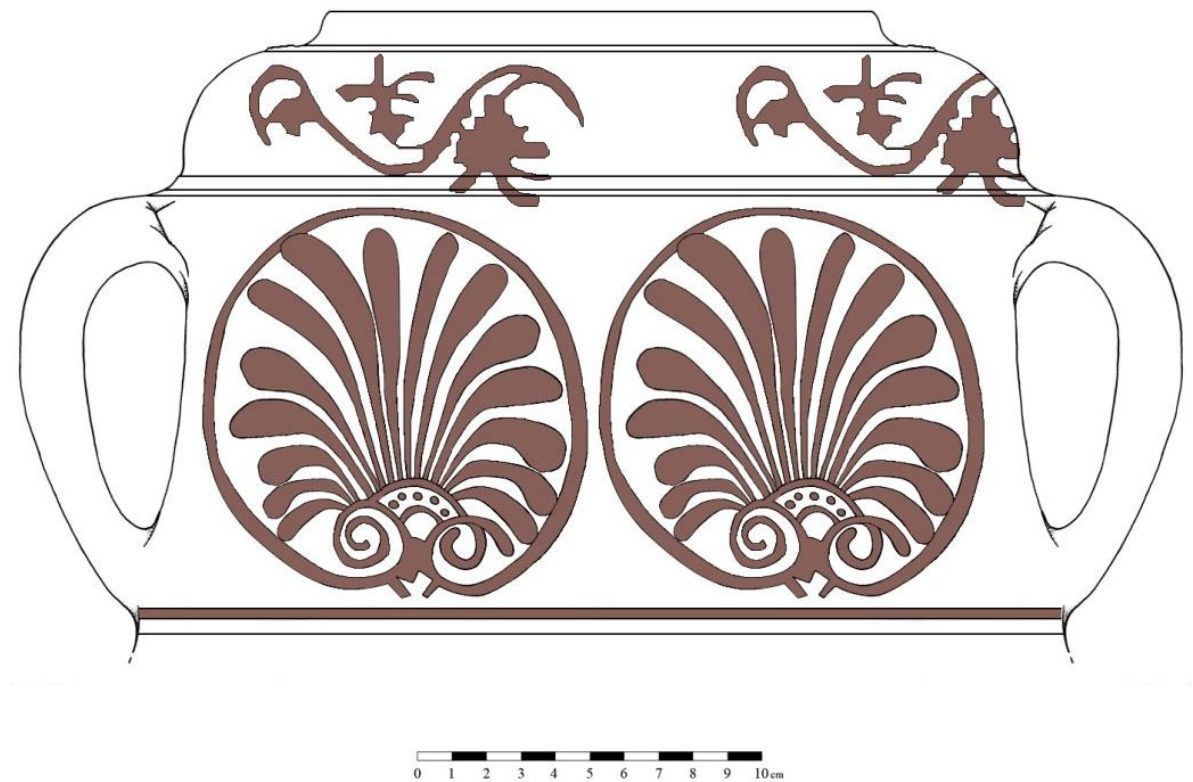

Fig. 13 - Reconstructive drawing of the central decoration of the amphora of the Area B. 

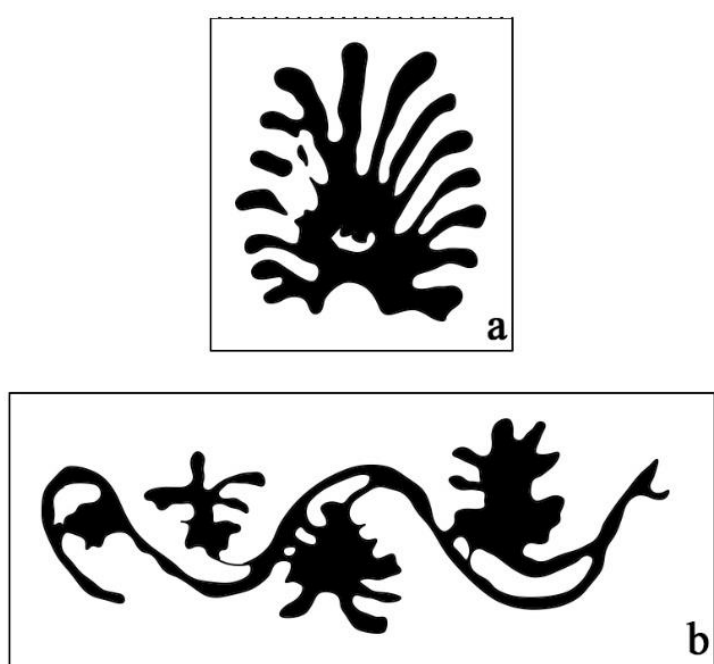

b

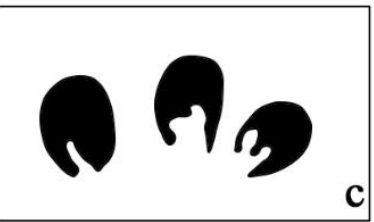

Fig. 14 - Typology of the painted decorative motifs on ostrich eggs (after Amadasi Guzzo 1988, 453). Three elements are evidenced: a) the palmetta with sixteen petals, like the palmetta of MB.89.24/3; b) the raceme hypothesized like the decoration on the shoulders; c) the triglyph with three drops, similar to the decoration on the handle.

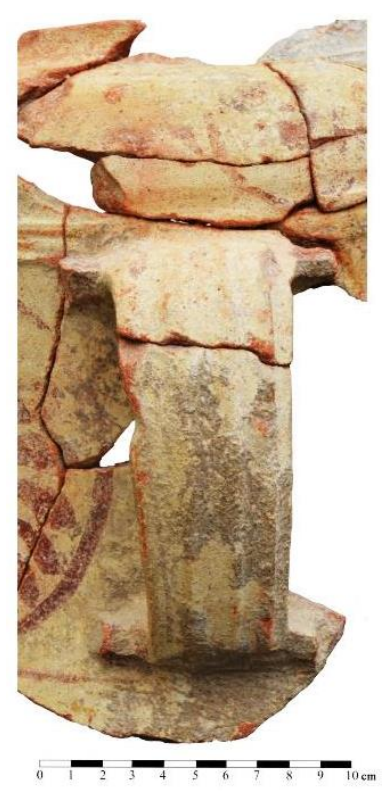

Fig. 15 - Detail of the decoration of the handle of the amphora of the Area B. 
Fig. 16 - The reconstructive hypothesis of the handle of the amphora of the Area B.

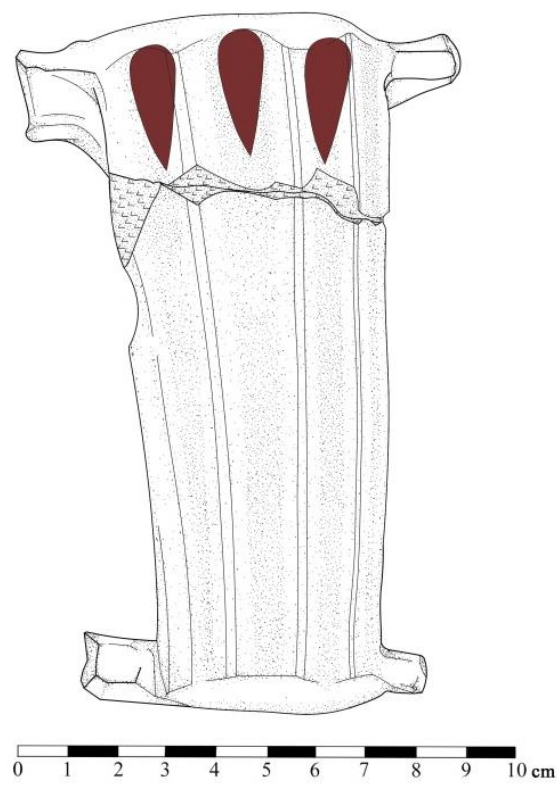

